\title{
PET/CT for Early Detection of COVID- I 9 Pneumonia: Diffuse Fluorodeoxyglucose Uptake in the Lungs without any Additional Changes in a Patient with Breast Cancer
}

\author{
PET/BT'de COVID-19 Erken Bulgusu: Meme Kanserli Hastada Sekel BT Bulguları \\ Zemininde Diffüz Artmış Akciğer Tutulumu
}

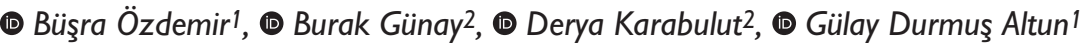 \\ I Trakya University Faculty of Medicine, Deparment of Nuclear Medicine, Edirne, Turkey \\ 2Trakya University Faculty of Medicine, Deparment of Radiology, Edirne, Turkey
}

\begin{abstract}
Coronavirus disease-2019 (COVID-19), which causes infections in the upper and lower respiratory tract, became a pandemic shortly after it was first diagnosed in Wuhan city, China. Many people are affected with high mortality rates and severe respiratory distress syndrome. During this pandemic, all physicians paid attention to the findings of COVID-19. Suggestive findings in ${ }^{18}$ fluorine-fluorodeoxyglucose $\left({ }^{18} \mathrm{~F}-\mathrm{FDG}\right)$ positron emission tomography/computed tomography (PET/CT) were characterized as increased ${ }^{18} \mathrm{~F}-\mathrm{FDG}$ uptake in bilateral peripheral consolidative areas and ground glass opacities. We aimed to show diffuse FDG uptake in PET images with indefinable lesions in CT as a suspicious finding for early COVID-19.

Keywords: ${ }^{18} \mathrm{~F}-\mathrm{FDG}$, COVID-19, PET/CT, SARS-CoV-2
\end{abstract}

\section{Öz}

Koronavirüs hastalığı-2019 (COVID-19) Çin'in Vuhan kentinde ortaya çıktıktan hemen sonra tüm dünyaya yayılmış alt ve üst solunum yolu enfeksiyonlarına yol açan bir virüstür. COVID-19, dünya genelinde birçok hastada asemptomatik hastalıktan respiratuvar distres sendromuna kadar geniş bir klinik spektrum oluşturmaktadır. Bu pandemi döneminde tüm klinisyenler COVID-19'un görüntüleme bulgularını bilmelidir. ${ }^{18}$ Florflorodeoksiglukoz ( ${ }^{18} \mathrm{~F}$-FDG) pozitron emisyon tomografisi/bilgisayarlı tomografide bilateral periferik konsolidasyon ve buzlu cam dansiteli alanlarda artmış ${ }^{18} \mathrm{~F}$-FDG tutulumu COVID-19 hastalarında karakteristiktir. Biz bu olgu örneğinde sekel akciğer dokusu zemininde yeni gelişen karakteristik tomografi bulgusu olmadan akciğerde diffüz artmış ${ }^{18} \mathrm{~F}-\mathrm{FDG}$ tutulumu ile tanı alan bir hastamızı sunduk.

Anahtar Kelimeler: ${ }^{18} \mathrm{~F}-\mathrm{FDG}$, COVID-19, PET/BT, SARS-CoV-2

Address for Correspondence: Büşra Özdemir MD, Trakya University Faculty of Medicine, Deparment of Nuclear Medicine, Edirne, Turkey Phone: +90 2842357641 E-mail: busraozdemir39@gmail.com ORCID ID: orcid.org/0000-0001-8540-0115 Received: 19.12.2020 Accepted: 12.05.2021 

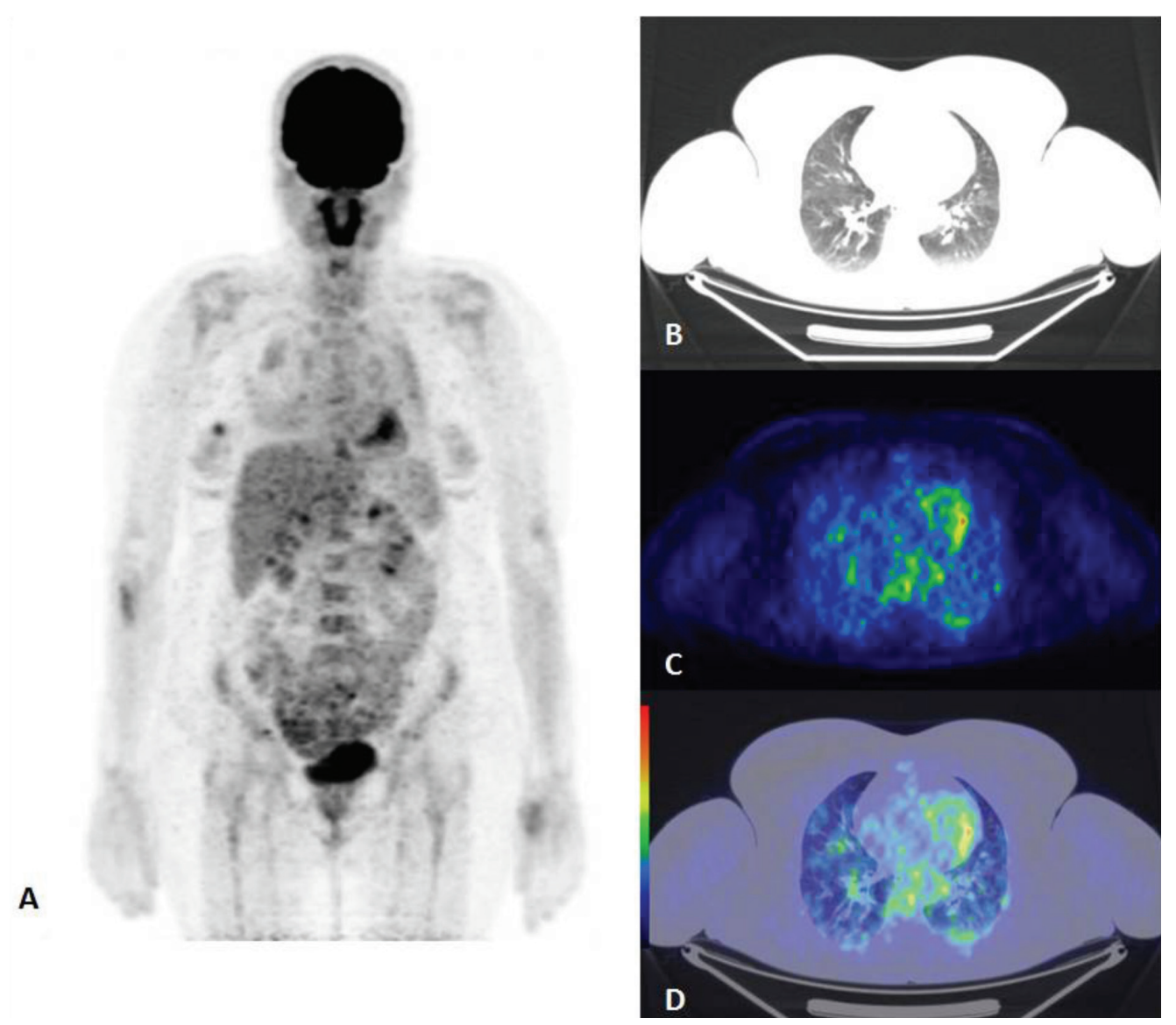

Figure 1. A 49-year-old female was biopsied for breast cancer and underwent positron emission tomography/computed tomography (PET/CT) for the staging and determination of disease extension. The patient was counseled for respiratory symptoms, such as cough, dyspnea, fatigue, and fever. She had no complaints or any known risky contacts. In maximum intensity projection images, (A) there was increased ${ }^{18 f l u o r i n e-f l u o r o d e o x y g l u c o s e}$ $\left({ }^{18} \mathrm{~F}-\mathrm{FDG}\right)$ uptake in the right retro-areolar region, right axillary lymph node, and bilateral lung fields. After correlative assessment of axial tomography (B), PET (C), and fusion images (D), this diffuse lung uptake was interpreted as suspicious of interstitial pneumonia, which is highly suggestive of Coronavirus disease-2019 (COVID-19) (1,2). The referring physician was contacted, and the patient underwent diagnostic computed tomography (CT) and reverse transcription-polymerase chain reaction (RT-PCR). Although the chest CT scan was undiagnostic, RT-PCR confirmed the COVID-19 infection. 


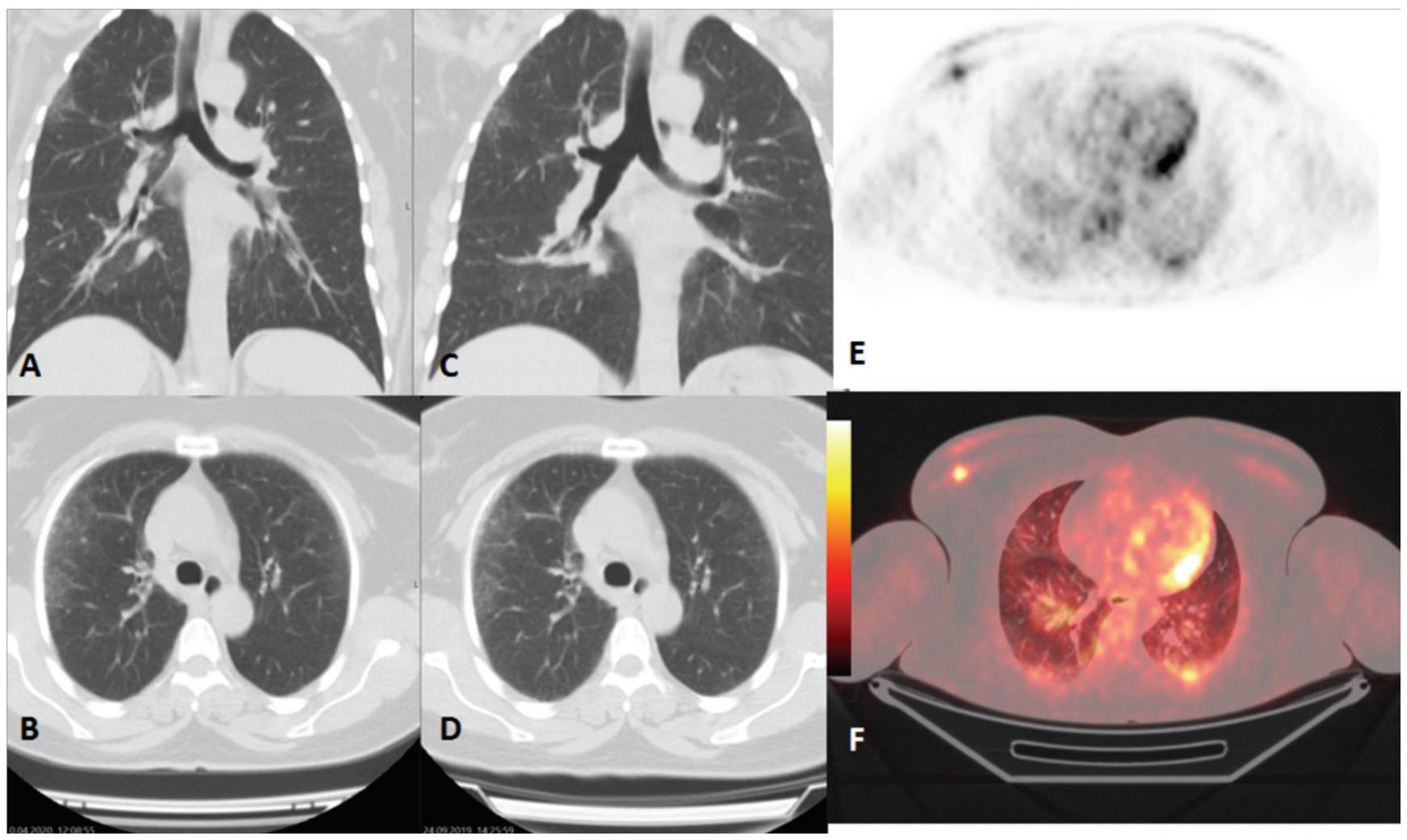

Figure 2. We compared the diagnostic axial and coronal chest CT images (A, B) taken to evaluate suspicion of COVID-19 on April 10, 2020, one day after PET/CT, with diagnostic axial and coronal chest CT (C, D) from September 2019. In both images, there was subpleural ground glass opacities and mild interseptal thickness accompanied by increased reticular density in the anterior segment of the upper lobe of the right lung and anterior segment of the upper lobe of the left lung. This was revealed as asymptomatic sequelae changes due to interstitial parenchymal disease. There were no specific changes that may be related to COVID-19 pneumonia. When we evaluated PET/CT's axial PET and hybrid images (E, F) on April 9, 2020, bilateral diffuse lung uptake without the addition of new CT findings was suggestive of COVID-19 on PCR, confirming COVID-19 positive in an asymptomatic patient. Findings of COVID-19 pneumonia may be summarized as peripheral ground glass opacites and consolidative areas in multiple segments (3). In this case, increased uptake was mainly due to increased glycolysis from leukocyte chemotaxis and accumulation related to bilateral interstitial inflammation (4). PET/CT may detect the earliest signs of interstitial pneumonia with high sensitivity (4). The ability to detect asymptomatic patients and prevent disease spread has recently become the most important aspect of PET/CT in this pandemic era of COVID-19 infection (5). 


\section{Ethics}

Informed Consent: The patient gave consent to the use of her data for medical purposes and signed the consent form during imaging.

Peer-review: Externally and internally peer-reviewed.

\section{Authorship Contributions}

Surgical and Medical Practices: B.Ö., B.G., Concept: B.Ö., D.K., Design: G.D.A., Data Collection or Processing: B.Ö., B.G., Analysis or Interpretation: G.D.A., Literature Search: D.K., G.D.A., Writing: B.Ö., B.G.

Conflict of Interest: No conflict of interest was declared by the authors.

Financial Disclosure: The authors declared that this study received no financial support.

\section{References}

1. Qin C, Liu F, Yen TC, Lan X. 18F-FDG PET/CT findings of COVID-19: a series of four highly suspected cases. Eur J Nucl Med Mol Imaging 2020;47:1281-1286.

2. Artigas C, Lemort M, Mestrez F, Gil T, Flamen P. COVID-19 Pneumonia Mimicking Immunotherapy-Induced Pneumonitis on 18F-FDG PET/ CT in a Patient Under Treatment With Nivolumab. Clin Nucl Med 2020;45:e381-e382.

3. Zhou Z, Guo D, Li C, Fang Z, Chen L, Yang R, Li X, Zeng W. Coronavirus disease 2019: initial chest CT findings. Eur Radiol 2020;30:4398-4406.

4. Becker W, Meller J. The role of nuclear medicine in infection and inflammation. Lancet Infect Dis 2001;1:326-333.

5. Albano D, Bertagna F, Bertoli M, Bosio G, Lucchini S, Motta F, Panarotto MB, Peli A, Camoni L, Bengel FM, Giubbini R. Incidental Findings Suggestive of COVID-19 in Asymptomatic Patients Undergoing Nuclear Medicine Procedures in a High-Prevalence Region. J Nucl Med 2020;61:632-636. 